\title{
An Assessment Framework for Small-Scale Coal Mining Based on Lean Thinking and Green Mining Concept
}

\author{
Berry Yuliandra ${ }^{1, *}$, Agus Sutanto ${ }^{1}$, Hendris Prasojo ${ }^{2}$
}

\begin{abstract}
Coal mining is one of Indonesia's important industrial sectors. However, the industry is also often seen as a major cause of landscape destruction and environmental unsustainability, especially by small-scale mining. This study aims to develop an assessment framework for small-scale mining based on the concept of lean thinking and green mining. Those concept can be used to ensure that the assessment process is oriented towards good mining practices and environmental conservation efforts. Focus of the study is coal mining business located in the city of Sawahlunto. The study was conducted using descriptive method with interview as primary data collection technique. In addition to primary data, secondary data are also collected from official documents, books, and reports on mining research in the city of Sawahlunto. Validation of criteria and indicators in the assessment framework is done using Focus Group Discussion (FGD) techniques with expert teams consisting of government, mining practitioners and academics. The proposed assessment framework consists of total 10 assessment criteria with 55 indicators.
\end{abstract}

Keywords-Assessment framework, lean thinking, green mining, coal mining, small-scale mining.

\section{INTRODUCTION}

$\mathrm{C}$ oal mining is one of Indonesia's important industrial sectors. The number of coal mining actors is relatively higher compared to other non-oil and gas mining sector, with mining areas spread in various parts of Indonesia. Although steam engines that use coal as fuel are no longer used today, coal is still widely used as fuel for steam power plants and industrial machinery that require substantial calories. Coal is also an important export commodities for the Asia Pacific region. The number of Indonesian coal exports in 2015 reached 328.4 million tons [1]. Regardless of the coal importance in terms of economy, the mining process has a tendency to generate waste and pollute the environment. The amount of waste and low process efficiency in the mining cycle are the main causes of landscape damage, rock extraction waste, and various other types of waste that can damage the environment. The imbalance between economic and environmental aspects causes coal mining is often labeled as unsustainable industrial sector.

Underground mining is a mining activity undertaken below the surface or not directly related to the outside air. Underground mining process can be done by Longwall or Room and Pillar methods. Although underground mining activities are considered more environmentally friendly than

${ }^{1}$ Department of Mechanical Engineering, Faculty of Engineering, Universitas Andalas, Kampus Limau Manis, Padang, Indonesia.

${ }^{2}$ Education and Training Center of Underground Mining, Ministry of Energy and Mineral Resources of the Republic of Indonesia, Sawahlunto, Indonesia.

*Correspondence to Berry Yuliandra, email: berry@ft.unand.ac.id. Tel.:+6285263676333. open pit mining (Approximately $73 \%$ of rocks extracted from open pit will end up as waste whereas for underground mines is only about 7\%), its recovery is considered poor. The underground coal mine with the room and pillar method has a recovery rate of $60-70 \%$, although the use of the longwall method can produce high cost for hallway maintenance. This condition emphasizes the importance of maximizing process efficiency and minimization of waste so that it can provide benefits not only to the mining business but also the government and communities living around the mining area.

Sawahlunto is one of the coal producing areas, mining city that has been operating since the Dutch colonial era. Sawahlunto's coal exploitation has reached 30 million tons, although it is estimated that there are still reserves of around 100 million tons so that mining processes in the city will continue for the coming years. After a large mining company has been out of operation since 2002, coal mining activities in Sawahlunto are operated by small-scale mining using underground mining methods. To date there are thirteen small-scale underground mining permits in Sawahlunto with most of its mining areas are in protected forest areas. Given its small scale nature and limited business capital, most of small-scale coal mining in Sawahlunto still do not pay much attention to the implementation of good mining practices, especially on issues related to the environment. There is a need for a special strategy from the government and business sectors to handle this problem. Assessment efforts are needed to develop appropriate strategies. The concept of lean thinking and green mining can be used to ensure that the assessment process is oriented towards good mining practices and environmental conservation efforts. Until this research has been conducted, there is still no evaluation instrument for small-scale coal mining that can be utilized to accommodate the assessment process, especially those built based on the concept of lean thinking and green mining.

The concept of lean thinking and green mining are two different concepts that prioritize efficiency in operations management. Research on lean thinking and green mining develops separately even though both concepts have a number of similarities that may lead to a synergistic relationship [2]. Lean thinking focuses on eliminating any activity that does not provide added value (waste) [3]. Waste is always present in every job and in every level of the organization [4], including mining industries. Meanwhile, green mining is more focused on energy saving, as well as minimization of waste, utilization of raw materials and water resources for mining activities. Lean thinking provides a platform for businesses to minimize the total use of materials, materials and chemical waste that will promote the culture of sustainable waste reduction [5]. Both lean thinking and green mining concepts can be applied sequentially or simultaneously, although simultaneous implementation will 
lead to better operational performance [6]. The concept of lean thinking and green mining has been used previously to design assessment models by Hasan et al. (2016), although the model is intended for supply chain performance assessment in rubber processing industry instead of coal mining industry [7]. This study aims to develop an assessment framework for artisanal and small-scale coal mining in the city of Sawahlunto based on a combination of lean thinking and green mining concepts.

\section{METHODOLOGY}

\section{A. Subsection Heading Here}

The research was conducted using descriptive method. Primary data comes from field research. The main research object is mining industry operates in Sawahlunto. Interviews are used as data collection techniques with miners as respondents. The interview process was assisted by a questionnaire. In addition to primary data, criteria and indicators for assessment framework are also determined using secondary data sourced from library research. Secondary data obtained in this way includes official documents, books, and research reports that have been conducted and published.

Primary and secondary data are used to develop criteria and indicators for small-scale coal mining assessment. The criteria and indicators are prepared using the following steps: (1) Define the context of lean thinking and green mining in small and medium coal mining industries; (2) Determining the existing constraints; (3) Determine the relationship between elements in the mining process; and (4) Identify the criteria and indicator of mining industry assessment. The concept of green mining is also in line with the implementation of good mining practices, so both are considered in the process of identifying criteria and assessment indicators together with the concept of lean thinking. The lean thinking and green mining context used to identify criteria and indicators can be seen in Table 1 . The identification results are validated using Focus Group Discussion (FGD) technique.

Table 1. Comparison between lean thinking, green mining, and good mining practice in mining context.

\begin{tabular}{|c|c|c|}
\hline $\begin{array}{ll}\text { Lean Thinking } \\
\end{array}$ & $\begin{array}{r}\text { Green Mining } \\
\end{array}$ & Good Mining Practice \\
\hline $\begin{array}{l}\text { - Identification of product value based on } \\
\text { customer perspective } \\
\text { - Identification of process map for each } \\
\text { product } \\
\text { - Waste elimination } \\
\text { - Organizing information and materials } \\
\text { - Tools and techniques for improvement } \\
\text { - Continuous improvement }\end{array}$ & $\begin{array}{l}\text { - Energy resources efficiency } \\
\text { - Minimizing emissions } \\
\text { - Efficiency of clean water utilization by } \\
\text { recycling water } \\
\text { - Tailings management to reduce } \\
\text { environmental impact } \\
\text { - Flue gas management to minimize } \mathrm{CO}_{2} \text { and } \\
\text { other chemical emissions } \\
\text { - Implementation of environmental } \\
\text { management system } \\
\text { - Reduction and utilization of hazardous and } \\
\text { toxic waste materials } \\
\text { - Implementation of the principle of } \\
\text { minimization, reuse and recycling of solid } \\
\text { waste non hazardous and toxic materials } \\
\text { - Minimization of air pollution and greenhouse } \\
\text { gas emissions } \\
\text { - Water efficiency and reduction of water } \\
\text { pollution } \\
\text { - Biodiversity protection }\end{array}$ & $\begin{array}{l}\text { - Environmental care } \\
\text { - Implementation of conservation principles } \\
\text { - Concern for worker safety and health } \\
\text { - Added value for regional / community } \\
\text { development }\end{array}$ \\
\hline
\end{tabular}

\section{RESUlT AND DisCUSSIONS}

The interview result analysis shows that the elements of assessment which based on the concept of lean thinking and green mining can be grouped into Resources and Environmental Aspects. Resources can be subdivided into: (1) Human resources; (2) Facilities and infrastructures; and (3) Governance, norms, standards and procedures. Human Resources (HR) is an important element of business management. Quantity and quality of human resources can influence mining industry ability to achieve their mission. facilities and infrastructure are main prerequisites for successful mining processes ranging from exploration to production. Governance, norms, standards and procedures are the third part of mining resources. Implementation of good mining practice requires a good governance system as well as standards, procedures, and norms that must always be adhered to as guidelines. Meanwhile, environmental aspects can be divided into: (1) Physical, chemical, and biological environment; and (2) Social, economic, and cultural environment.

The development of assessment criteria through analysis of secondary data are based on the context of these groups. Human Resources is considered as a separate criterion from other criteria. Facilities and infrastructure were developed into four criteria: (a) Mining process; (b) Corporate governance; (c) OHS management system; and (d) Sustainability. Assessments based on governance, norms, 
standards and procedures are divided into six criteria, among others: (a) Mining process; (b) Mining products; (c) Corporate Governance; (d) OHS management system; (e) Risk management system; and (f) Environmental systems. Physical, chemical, and biological environments are broken down into two criteria: (a) Mining process; and (b) Environmental systems. The social, economic, and cultural environment is divided into three criteria: (a) Community development; (b) Sustainability; and (c) Economy. The overall criteria formed are combined to form an assessment framework. This will lead to the incorporation of several of the same criteria but derived from different groups. Further analysis of secondary data yields a series of basic idea of assessment indicators based on the concept of lean thiking, green mining, and good mining practice. Assessment criteria and basic idea of indicators can be seen in Table 2 .

Table 2. Basic idea for the development of small-scale coal mining assessment indicators.

\begin{tabular}{|c|c|c|c|}
\hline \multirow{2}{*}{$\begin{array}{c}\text { Assessment } \\
\text { Criteria }\end{array}$} & \multicolumn{3}{|c|}{ Basic Concepts } \\
\hline & Lean Thinking & Green Mining & Good Mining Practice \\
\hline $\begin{array}{l}\text { Human } \\
\text { Resources }\end{array}$ & $\begin{array}{l}\text { - Worker quality } \\
\text { - Worker motivation level }\end{array}$ & & - Worker safety and health \\
\hline $\begin{array}{l}\text { Mining } \\
\text { Process }\end{array}$ & $\begin{array}{l}\text { - Exploration technology } \\
\text { - Equipment }\end{array}$ & & $\begin{array}{l}\text { - Mining Engineering } \\
\text { - Environmental management }\end{array}$ \\
\hline $\begin{array}{l}\text { Mining } \\
\text { Products }\end{array}$ & $\begin{array}{l}\text { - Consumer needs } \\
\text { - Coal content } \\
\end{array}$ & & \\
\hline $\begin{array}{l}\text { Corporate } \\
\text { Governance }\end{array}$ & $\begin{array}{l}\text { - Asset management } \\
\text { - Implementation of mining governance } \\
\text { - Sanctions and rewards implementation }\end{array}$ & & \\
\hline $\begin{array}{l}\text { OHS } \\
\text { Management } \\
\text { System }\end{array}$ & & & $\begin{array}{l}\text { - Availability of safety equipment } \\
\text { - OHS resources and training } \\
\text { - Potential hazards and OHS risks } \\
\text { identification } \\
\text { - OHS planning } \\
\text { - OHS procedures } \\
\text { - OHS evaluation and documentation }\end{array}$ \\
\hline $\begin{array}{l}\text { Risk } \\
\text { Management } \\
\text { System }\end{array}$ & & $\begin{array}{l}\text { - Risk management procedures } \\
\text { - Risk management evaluation } \\
\text { and documentation } \\
\text { - Risk identification } \\
\text { - Risk management plan } \\
\text { - Risk management resources } \\
\end{array}$ & \\
\hline $\begin{array}{l}\text { Environmental } \\
\text { Systems }\end{array}$ & & $\begin{array}{l}\text { - Waste Management } \\
\text { - Water utilization } \\
\text { - Biodiversity protection }\end{array}$ & \\
\hline $\begin{array}{l}\text { Community } \\
\text { Development }\end{array}$ & & & - Community development resources \\
\hline Sustainability & $\begin{array}{l}\text { - Equipment maintenance } \\
\text { - Resource efficiency }\end{array}$ & & \\
\hline Economy & - Business network & & \\
\hline
\end{tabular}

The assessment framework is validated by a team of experts through FGD. The expert team consists of government, mining practitioners and academics. The validation results can be seen in Figure 1. Assessment indicators were developed based on the basic idea that has been formed in Table 2 to accommodate the assessment process. The proposed indicators are obtained with the following details: 6 indicators on HR criteria, 6 indicators on
Mining Process criteria, 2 indicators on Mining Products criteria, 6 indicators on Corporate Governance criteria, 11 indicators on OHS Management System criteria, 8 indicators on Risk Management System criteria, 10 indicators on Environmental System criteria, 1 indicators on Community Development criteria, 3 indicators on Sustainability criteria, and 2 indicators on Economy criteria. Proposed indicators for each group of criteria can be found in Table 3. 


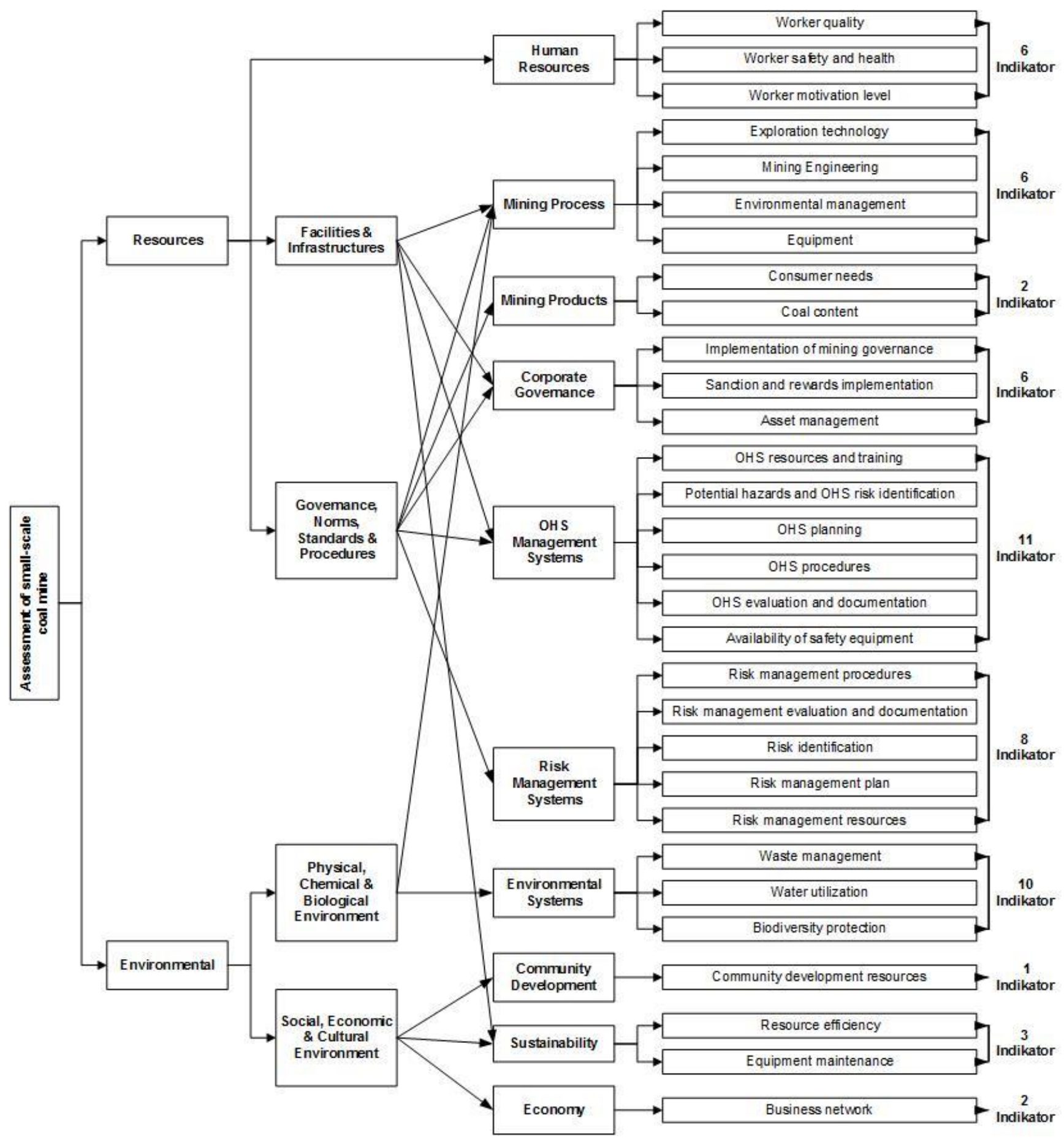

Fig. 1. Assessment framework for small-scale coal mining industry based on lean thinking and green mining concept. 
Table 3. Proposed assessment indicators for small-scale coal mining industry based on lean thinking and green mining concept.

\begin{tabular}{|c|c|c|}
\hline & No. & Indicators of each Variable \\
\hline \multirow[t]{7}{*}{$\mathbf{S}$} & & Human Resource \\
\hline & S1 & The percentage of qualified recruitment \\
\hline & S2 & Improvement of basic competence, certification and managerial \\
\hline & S3 & The level of employees and their family health quality \\
\hline & S4 & The level of $\mathrm{K} 3$ implementation \\
\hline & S5 & The percentage rate of labor productivity \\
\hline & S6 & The percentage level of worker motivation \\
\hline \multirow[t]{7}{*}{$\mathbf{P}$} & & Mining Process \\
\hline & P1 & The level of exploration technology used \\
\hline & $\mathrm{P} 2$ & Mining techniques applied are guided by rules \\
\hline & P3 & The percentage of erosion and sedimentation control measures \\
\hline & P4 & Waste reduction rate \\
\hline & P5 & The equipment investment value \\
\hline & P6 & Overall Equipment Effectiveness (OEE) \\
\hline \multirow[t]{3}{*}{$\mathbf{H}$} & & Mining Products \\
\hline & H1 & The level of compliance with consumer needs \\
\hline & $\mathrm{H} 2$ & The percentage of fixed carbon \\
\hline \multirow[t]{7}{*}{$\mathbf{T}$} & & Corporate Governance \\
\hline & $\mathrm{T} 1$ & The percentage level of governance implementation quality \\
\hline & $\mathrm{T} 2$ & Number of affirmations and strict sanctions on work ethics violations \\
\hline & T3 & The level of operation efficiency and assets maintenance \\
\hline & T4 & The quality level of routine checks on asset conditions and performance \\
\hline & T5 & The certainty level of assets rehabilitation or replacement \\
\hline & T6 & Total disposal or asset rationalization \\
\hline \multirow[t]{11}{*}{$\mathbf{L}$} & & Environmental Systems \\
\hline & L1 & Total resource for hazardous and toxic waste utilization \\
\hline & L2 & The number of personnel with hazardous and toxic waste utilization competence \\
\hline & L3 & Total resource for non hazardous waste utilization \\
\hline & L4 & The number of personnel with waste utilization competence (non hazardous waste) \\
\hline & L5 & Total resources for air pollution reduction \\
\hline & L6 & The number of personnel with competencies related to air pollution reduction measures \\
\hline & L7 & Total resources for water efficiency and waste water pollution reduction \\
\hline & L8 & The number of personnel with relevant water efficiency and waste water pollution reduction competencies \\
\hline & L9 & The number of personnel with competencies related to biodiversity protection \\
\hline & L10 & The number of cooperation with other organizations related to biodiversity protection \\
\hline \multirow[t]{2}{*}{$\mathbf{P}$} & & Community Development \\
\hline & P1 & The number of personnel with competencies related to community development \\
\hline \multirow[t]{4}{*}{$\mathbf{C}$} & & Sustainability \\
\hline & $\mathrm{C} 1$ & Electricity and fuel savings as well as periodic inspection of equipment and operational vehicles \\
\hline & $\mathrm{C} 2$ & The funding for ancillary equipment maintenance \\
\hline & $\mathrm{C} 3$ & Total periodic maintenance and inspection of gas emissions on ancillary equipment \\
\hline \multirow[t]{12}{*}{$\mathbf{K}$} & & OHS Management System \\
\hline & K1 & Number of resources used to implement occupational health and safety (OHS) \\
\hline & K2 & The number of competent workers for potential hazards and OSH risk assessment \\
\hline & K3 & Plans related to specific products, processes, projects or workplaces \\
\hline & K4 & Availability of procedures and work instructions for product use \\
\hline & K5 & Availability of supplier evaluation procedures based on OSH requirements \\
\hline & K6 & The number of competent personnel for risk assessment on work process \\
\hline & K7 & The number of suitable protective equipment \\
\hline & K8 & Availability of procedures to identify potential emergency \\
\hline & K9 & Labor health monitoring system \\
\hline & K10 & Availability of hazard reporting procedures \\
\hline & K11 & The number and type of suitable OSH training \\
\hline \multirow[t]{9}{*}{$\mathbf{R}$} & & Risk Management System \\
\hline & R1 & Maximum Residue Limits (MRL) \\
\hline & R2 & Availability of risk management reporting scheme \\
\hline & R3 & Availability of risk management Standard Operating Procedure (SOP) \\
\hline & R4 & Number of risk management resources \\
\hline & R5 & Number of resources allocated for risk management \\
\hline & R6 & Availability of risk management plan \\
\hline & R7 & Availability of alternative risk management plans \\
\hline & R8 & Level of risk owner's involvement as a source of information on risk management implementation \\
\hline \multirow[t]{3}{*}{$\mathbf{E}$} & & Economy \\
\hline & E1 & The number of cooperation with business and local partners \\
\hline & E2 & The number of assisted partners and distribution cooperation cluster \\
\hline
\end{tabular}




\section{CONCLUSION}

The research has resulted in an assessment framework for small-scale coal mining industry. The assessment framework is based on the concept of lean thinking and green mining, which is complemented by consideration of good mining practices due to their conformity with the green mining concept. The assessment framework is composed of 10 assessment criteria with the following details: (1) Human Resources criteria consisting of 6 assessment indicators; (2) Mining Process criteria consisting of 6 assessment indicators; (3) Mining Products criteria consisting of 2 assessment indicators; (4) Corporate Governance criteria consisting of 6 assessment indicators; (5) OHS Management System criteria consisting of 11 assessment indicators; (6) Risk Management System criteria consisting of 8 assessment indicators; (7) Environmental System criteria consisting of 10 assessment indicators; (8) Community Development criteria consisting of 1 assessment indicators; (9) Sustainability criteria consisting of 3 assessment indicators; and (10) Economy criteria consisting of 2 assessment indicators. Total there are 55 proposed indicators that can be used to assess small-scale coal mining. Further research can be undertaken to develop this assessment framework, which is the preparation of standards for each indicator and criteria.

\section{ACKNOWLEDGMENT}

The authors greatly acknowledge the Faculty of Engineering, Andalas University which provided the financial support for this research with contract No. 055/UN.16.09.D/PL/2017, DIPA-UNAND Funding Scheme 2017.

\section{REFERENCES}

[1] D. Iswanto, Statistik Pertambangan Non Minyak dan Gas Bumi. Jakarta: Badan Pusat Statistik, 2016.

[2] G. Johansson and E. Sundin, "Lean and green product development: Two sides of the same coin?," J. Clean. Prod., vol. 85, pp. 104-121, 2014.

[3] J. P. Womack and D. T. Jones, Lean thinking: banish waste and create wealth in your corporation. Free Press, 2003.

[4] K. W. Dailey, The lean manufacturing pocket handbook. DW Pub, 2003.

[5] M. A. Taubitz, "Lean, Green \& Safe," Prof. Saf., vol. 55, no. 5, pp. 39-46, 2010.

[6] A. Galeazzo, A. Furlan, and A. Vinelli, "Lean and green in action: Interdependencies and performance of pollution prevention projects," J. Clean. Prod., vol. 85, pp. 191-200, 2014.

[7] A. Hasan, B. Yuliandra, and E. P. Putra, "Perancangan Model Pengukuran Kinerja Rantai Pasok Berbasis Lean dan Green menggunakan Balance Scorecard di PT. P\&P Lembah Karet," J. Optimasi Sist. Ind., vol. 15, no. 1, p. 33, Apr. 2016. 